\title{
Surgical treatment of lumbar disc herniation in Aceh, Indonesia: Description in 28 patients
}

\author{
Jonny Karunia Fajar ${ }^{1 *}$, Azharuddin Azharuddin² \\ ${ }^{1}$ Medical Research Unit, School of Medicine, Syiah Kuala University, Banda Aceh, Indonesia, \\ ${ }^{2}$ Department of Orthopedic and Traumatology, Zainoel Abidin General Hospital, Banda Aceh, Indonesia
}

\begin{abstract}
Introduction: Several studies have reported the incidence of herniated nucleus pulposus (HNP) in some hospitals. Surgery is one of the options in HNP management. HNP surgery results in Aceh have not been reported yet. Therefore, this study reported the HNP surgery in Zainoel Abidin General Hospital, Banda Aceh, during the period of 2010-2012.
\end{abstract}

Methods: This was a descriptive retrospective survey conducted in Zainoel Abidin General Hospital, Banda Aceh, at August-September 2012.

Results: The incidence of HNP who underwent surgery was 28 patients. There was no HNP case in the age Group I (0-18 years), 7 patients (25\%) were age Group II (19-40 years), and 21 patients (75\%) were age Group III (over 40 years). Based on HNP location, there was no HNP located in the L1-L2 and L3-L4, one patient (3.57\%) was L2-L3, 20 patients (71.42\%) were L4-L5, three patients $(10.71 \%)$ were L5-S1, and there were four HNP patients in multiple lumbar (14.28\%). Laminectomy was the most common type of surgery performed (27 patients or $96.42 \%$ ), followed by laminotomy (one patients or $3.57 \%$ ).

Conclusion: There was a significant association between the incidence of HNP with age but not with gender. In summary, the most common lumbar disc herniation was in L4-L5. Laminectomy was the most common procedure performed in HNP patient in Aceh.

Key words: Herniated nucleus pulposus surgery; herniated nucleus pulposus; lumbar disc herniation

\section{INTRODUCTION}

Herniated nucleus pulposus (HNP) is a disease in which the intervertebral disc (soft gel disc or nucleus pulposus) pressed and ruptured, resulting in narrowing and pressed of spinal nerve. The cause

\footnotetext{
*Corresponding author: Jonny Karunia Fajar, Jl. Tanoeh Abe, Darussalam, Banda Aceh 231 11, Indonesia. Phone: +62(0)81235522287. Fax: +62(0)6517551843.

E-mail: gembyok@gmail.com
}

Submitted: 10 May 2017/Accepted: 30 August 2017

DOI: https://doi.org/10.17532/jhsci.2017.433 of HNP is still unclear. However, several conditions have been associated with HNP incidence including trauma, lifting injuries, age, sex, smoking, exposure to vehicle vibration, and idiopathic (1). It was also reported that HNP is more common among full-time workers and smokers (2). HNP causes large morbidity in patient because HNP triggers to release inflammatory mediators that can directly cause pain, even in the absence of nerve compression (3). The incident and prevalence of HNP have been widely reported vary in some countries. The prevalence of symptomatic 
HNP is about $1.03 \%$ of the population in Finland (4), $1.6 \%$ in the US (5), and $2.2 \%$ in England (6). Prasad et al. (7) examined the epidemiology of HNP in tertiary care hospitals in India which showed that the incidence of HNP was approximately $13.3 \%$ of the population. Previously, Anderson (8) showed that the incidence of sciatica caused by HNP was about $1-3 \%$ of the population. Overall, the incidence of HNP is about $0.7-9.0 \%$ of the population and the prevalence is about $2.2-8 \%$ of the population (2).

Surgery is one of the options on HNP management. Although 90\% quality of life patients improves with nonsurgical management, $10-15 \%$ of cases require surgical management (9). Several studies have reported that HNP surgery has good results. Tejapongverachai et al. (10) reported that surgery (discectomy procedure) in HNP patients has a good effectiveness. Another study (11) documented that percutaneous disc decompression technique has a good effectiveness in relieving radicular pain among HNP patients. Koga et al. (12) reported a small surgical incision in HNP patients resulted in good outcome.

However, recently, there has been no study HNP surgery in Aceh. In this context, this study was conducted to explore some aspects of HNP surgery in Zainoel Abidin General Hospital, Banda Aceh.

\section{METHODS}

\section{Study design}

This study was a descriptive retrospective survey in Zainoel Abidin General Hospital, Banda Aceh, in August-September 2012. Sample of this study was all HNP patients who underwent surgery in Zainoel Abidin General Hospital during the period of 2010 2012. This study was approved by the Institutional Review Board, Zainoel Abidin General Hospital.

\section{Data collection}

Data were collected from Medical Record Department of Zainoel Abidin General Hospital. Between January 2010 and August 2012, 28 HNP patients who underwent surgery were documented. The following documented and potentially clinically relevant variables were employed for all outcomes: Sex, age, inter-vertebral level of the intervention, and type of surgery.

\section{Statistical analysis}

All data obtained were presented descriptively and analyzed using Spearman test to compare patient characteristics: Gender, age, inter-vertebral level of the intervention, and type of surgery with HNP incidence.

\section{RESULTS}

This research reported the incidence of surgical on HNP patients in Zainoel Abidin General Hospitals. The total number of HNP patients who underwent surgery in Zainoel Abidin General Hospital in the period of 2010-2012 is shown in Figure 1. In addition, this study also reported a relationship between patient characteristics (sex and age) and HNP incidence, HNP location and type of procedure-related HNP (Table 1).

Vast majority (75\%) patients, in this study, were more than 40 years, and the incidence of HNP in men and women was equal. In this study, we found that most HNP patients were located in the lumbar $(89.28 \%)$. Surgery is one of the procedures for patients with symptomatic HNP to improve patient

TABLE 1. The relationship between patient characteristics, herniated nucleus pulposus location, and type of procedure and herniated nucleus pulposus incidence

\begin{tabular}{lcc}
\hline Variables & $\mathrm{n}(\%)$ & $\mathrm{p}$ \\
\hline Age & $7(25)$ & 0.003 \\
$\begin{array}{l}19-40 \\
>40\end{array}$ & $21(75)$ & \\
Gender & $14(50)$ & $\mathrm{NS}$ \\
$\quad$ Male & $14(50)$ & \\
$\quad$ Female & & \\
HNP location & $25(89.28)$ & 0.000 \\
Lumbar & $3(10,72)$ & \\
Sacral & & \\
Level of lumbar disc & $1(3.57)$ & 0.000 \\
L2-L3 & $20(71.42)$ & \\
L4-L5 & $3(10.71)$ & \\
L5-S1 & $4(14.28)$ & \\
$\quad$ Multiple location & & \\
Type of procedure & $27(96.42)$ & 0.001 \\
Laminectomy with discectomy & $1(3.57)$ & \\
Laminotomy with discectomy &
\end{tabular}

NS: Not significant; HNP: Herniated nucleus pulposus 


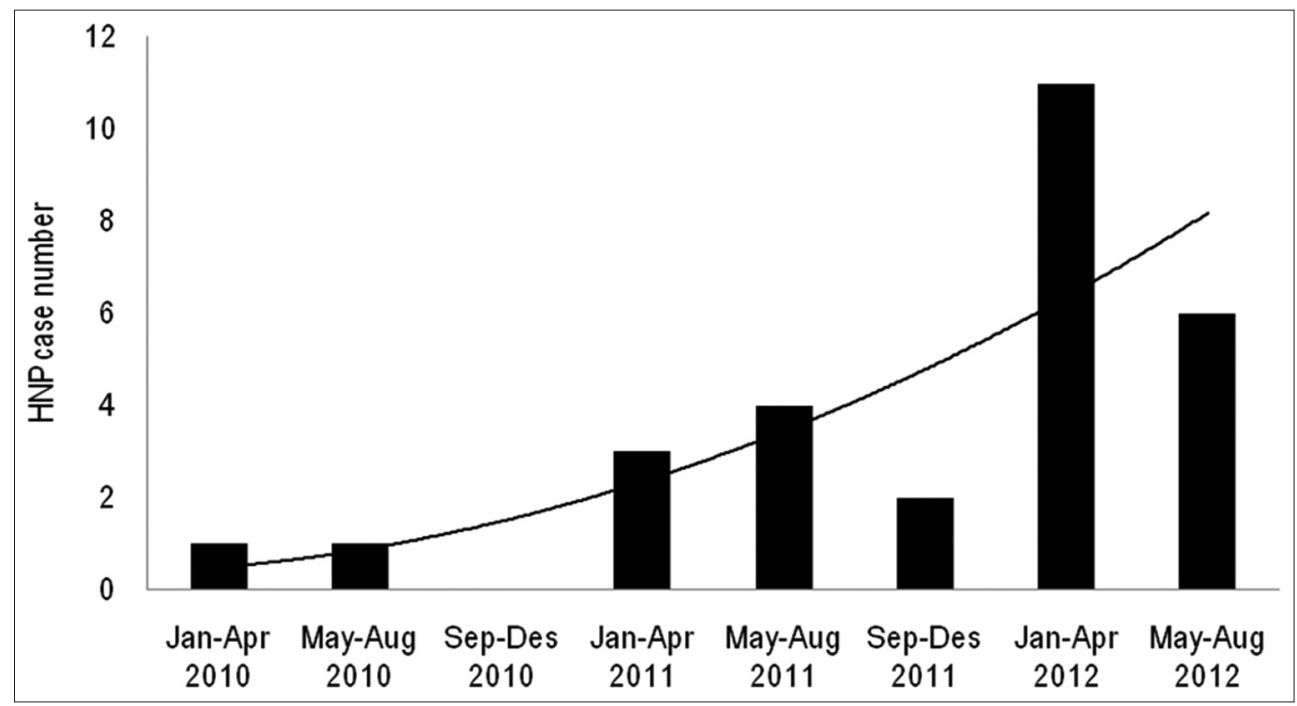

FIGURE 1. Distribution of herniated nucleus pulposus cases in Zainoel Abidin General Hospital during the period of 2010-2012. There were 28 herniated nucleus pulposus patients who underwent surgery in given period; The highest incidence rate was in period JanuaryApril 2012 with 11 patients.

condition $(13,14)$. In this study, laminectomy with discectomy was the most common procedure used in HNP patients $(96.42 \%)$ followed by laminotomy with discectomy.

\section{DISCUSSION}

Age is often associated with the risk of some diseases. However, the association between age and incidence of HNP is still controversial. This study found that age was associated with HNP. The theoretical concept of the relationship between age and HNP incidence is still not well understood. Katsuno et al. (15) conducted a study to elucidate the relationship between age with the production of nitride oxide (NO) and cytokines, which is associated with nucleus pulposus cells. They showed that NO levels increase with age. It indicated that the inflammatory reaction increases with increasing of age. It also showed that age was associated with cytokine imbalance. Stress and aging affect the extracellular matrix components and changes in immune responses. Katsuno et al. (15) suggested that the nucleus pulposus has cell-mediated immunity activity higher in young than in the elderly. On the contrary, there was no significant association between the incidences of HNP due to trauma with patient age (16).
Interestingly, Yorimitsu et al. (17) showed that the majority of the HNP patients were $<35$ years of age. The incidence of HNP in young was not widely studied yet. However, it is suspected that there is the role of gene. Higashino et al. (1) found that patients aged $<40$ years with tryptophan allele $(\operatorname{Trp} 2)$ showed more severe disc degeneration than those who do not have the allele Trp2. Conversely, patients aged 40 years or older showed no significant association between allele Trp 2 and disc degeneration. This data suggested that the allele $\operatorname{Trp} 2$ is an age-dependent risk factor for the severity of disc degeneration in young patients with HNP.

The association between sexes with the incidence of HNP is still not well understood. This indicates that there is no clear correlation between sexes with the risk of HNP. This result is consistent with the results of previous studies. Rizzolo et al. (16) found that there was no significant association between HNP due to trauma with sex. This is also supported by Burke et al. (18) which examines the pro-inflammatory mediators in patients with HNP. It showed that interleukin (IL)-6, IL-8, and prostaglandin E2 were increased in patients with HNP, but increased inflammatory mediators are not related to the gender of the patient.

HNP can occur in the cervical, thoracic, lumbar, and sacral. In this study, most of HNP was located 
in lumbar (89.28\%). This result is consistent with the study of computed tomography scans performed by Delauche-Cavallier et al. (19). It showed that lumbar HNP was most frequently found among patients observed. In line with data, Varanasi (20) also showed that most cases of HNP (95\%) occurred in the lumbar region, followed by cervical and thoracic regions, about $0.5-4 \%$ of all cases. In addition, this study found that most patients had HNP at L4-L5 followed by L5-S1 and L2-L3. This result was consistent with previous studies that the most common level involved in lumbar disc herniation was L4-L5 followed by L5-S1 (21-23). A recent study conducted by Udama et al. (24) also showed that the most common site of HNP was in the lumbar and the site of predilection was L4-L5 disc cartilage.

Surgery in patients with lumbar HNP is the main choice of therapy. Weinstein et al. (25) compared the results of non-surgical management with surgery in patients with lumbar HNP. It indicates that surgery may improve the symptoms of the patient much better than non-surgical management. Peul et al. (26) also showed that surgery in patients with sciatica due to lumbar HNP can improve symptoms faster compared with conservative management. Discectomy is a common and generally successful treatment for lumbar disc herniation (27). Methods for performing discectomy are divided into minimal invasive and conventional. Conventional methods to perform discectomy are laminotomy and laminectomy (28). The effectiveness of laminectomy in patients with HNP has been reported by several studies. Siddiq et al. (29) found that laminectomy is the most preferred surgery in patients with HNP. Although laminectomy is a type of surgery that is considered expensive (30), this type of surgery is considered effective for recurrent HNP (31). Hirsch et al. (32) showed that discectomy clearly associated with reduced symptoms in patients with HNP. Koga et al. (12) showed that discectomy is the gold standard surgery for patients with a recurrent HNP. Glenn et al. (33) also showed that discectomy is the gold standard for recurrent HNP and herniation that has been occurred in three locations. The types of surgery on HNP differ according to location. Tejapongverachai et al. (10) suggested perform discectomy surgery on patients with thoracic HNP.
Nevertheless, several studies have reported the incidence of recurrent HNP complications after discectomy. Some studies have reported the incidence of recurrent HNP after discectomy $(34,35)$.

\section{CONCLUSION}

In summary, in this study, HNP was common in the elderly and there was no association between HNP incidence and sex. Lumbar, specifically L4-L5 was the most common location for HNP, and laminectomy with discectomy was the most common procedure performed followed by laminotomy with discectomy.

\section{CONFLICTS OF INTEREST}

Authors report no conflict of interest.

\section{REFERENCES}

1. Higashino K, Matsui Y, Yagi S, Takata Y, Goto T, Sakai T, et al. The alpha2 Type IX collagen tryptophan polymorphism is associated with the severity of disc degeneration in younger patients with herniated nucleus pulposus of the lumbar spine. Int Orthop 2007;31(1):107-11.

https://doi.org/10.1007/s00264-006-0117-8.

2. Levin JH, Smuck MW. Radiculopathy from herniation of the nucleus pulposus: Epidemiology, pathophysiology and natural history. J Back Musculo Rehab 2007;20:97-101.

https://doi.org/10.3233/BMR-2007-202-307.

3. Shamji MF, Jing L, Chen J, Hwang P, Ghodsizadeh O, Friedman AH, et al. Treatment of neuroinflammation by soluble tumor necrosis factor receptor type II fused to a thermally responsive carrier. J Neurosurg Spine 2008;9(2):221-8.

https://doi.org/10.3171/SPI/2008/9/8/221.

4. Heliövaara M, Knekt P, Aromaa, A. Incidence and risk factors of herniated lumbar intervertebral disc or sciatica leading to hospitalization. J Chronic Dis. 1987;40(3):251-8.

https://doi.org/10.1016/0021-9681(87)90161-5.

5. Deyo RA, Tsui-Wu YJ. Descriptive epidemiology of low-back pain and its related medical care in the united states. Spine (Phila $\mathrm{Pa}$ 1976) 1987;12(3):264-8.

https://doi.org/10.1097/00007632-198704000-00013.

6. Lawrence JS. Reumatism in Populations. London: Heinemann; 1977.

7. Prasad R, Hoda MF, Dhakal MM, Singh K, Srivastava A, Sharma V. Epidemiological characteristics of lumbar disc prolapse in a tertiary care hospital. Intern J Neurosurg 2006;3(1).

8. Andersson GB. The epidemiology of spinal disorders. In: Frymoyer JW editor. The Adult Spine: Principles and Practice. $2^{\text {nd }}$ ed. New York: Raven Press; 1997.

9. Maity A, Mondal BC, Saha D, Roy DS. A prospective randomized, double-blind, controlled clinical trial comparing epidural butorphanol plus corticosteroid with corticosteroid alone for sciatica due to herniated nucleus pulposus. Perspect Clin Res 2012;3(1):16-21.

https://doi.org/10.4103/2229-3485.92302.

10. Tejapongverachai T, Kuptaniratsaikul S, Ittiravivong $\mathrm{P}$, Bohiman $\mathrm{HH}$ Herniated nucleus pulposus of thoracic spine: Treated by anterior trans 
thoracic diskectomy. Chula Med J 2002;48:802-12.

11. Lee SH, Derby R, Sul Dg, Hong Jw, Kim GH, Kang S, et al. Efficacy of a new navigable percutaneous disc decompression device (L'DISQ) in patients with herniated nucleus pulposus related to radicular pain. Pain Med 2011;12(3):370-6. https://doi.org/10.1111/j.1526-4637.2011.01064.x.

12. Koga S, Sairyo K, Shibuya I, Kanamori Y, Kosugi T, Matsumoto H, et al. Minimally invasive removal of a recurrent lumbar herniated nucleus pulposus by the small incised microendoscopic discectomy interlaminar approach. Asian J Endosc Surg 2012;5(1):34-7.

https://doi.org/10.1111/j.1758-5910.2011.00118.x.

13. Kraemer J. Intervertebral Disc Diseases: Cause, Diagnosis, Treatment, and Prophylaxis. $3^{\text {rd }}$ ed. Notzingen: George Thieme Verlag KG; 2009.

14. Phillips F, Lauryssen C. The Lumbar Intervertebral Disc: Decompressive Surgery for Herniated Nucleus Pulposus (open, micro, and minimally invasive approaches). New York: Thieme Medical Publisher Inc.; 2010.

https://doi.org/10.1055/b-002-72260.

15. Katsuno R, Hasegawa T, Iwashina T, Sakai D, Mikawa Y, Mochida J, et al. Age-related effects of cocultured rat nucleus pulposus cells and macrophages on nitric oxide production and cytokine imbalance. Spine (Phila Pa 1976) 2008;33(8):845-9.

https://doi.org/10.1097/BRS.0b013e31816b4685.

16. Rizzolo SJ, Piazza MR, Cotler JM, Balderston RA, Schaefer D, Flanders A, et al. Intervertebral disc injury complicating cervical spine trauma. Spine (Phila Pa 1976) 1991;16(6s):S187-9.

17. Yorimitsu E, Chiba K, Toyama Y, Hirabayashi K. Long-term outcomes of standard discectomy for lumbar disc herniation: A follow-up study of more than 10 years. Spine (Phila Pa 1976) 2001;26(6):652-7. https://doi.org/10.1097/00007632-200103150-00019.

18. Burke JG, Watson RW, McCormack D, Dowling FE, Walsh MG, Fitzpatrick JM. Intervertebral discs which cause low back pain secrete high levels of proinflammatory mediators. J Bone Joint Surg 2002;84-B:196-201.

19. Delauche-Cavallier MC, Budet C, Laredo JD, Debie B, Wybier M, Dorfmann $\mathrm{H}$, et al. Lumbar disc herniation. Computed tomography scan changes after conservative treatment of nerve root compression. Spine (Phila Pa 1976) 1992;17(8):927-33.

https://doi.org/10.1097/00007632-199208000-00010.

20. Varanasi VJ. Lumbar disc herniation. Orthopedic Muscul Syst 2012;1(1): 1000-101. https://doi.org/10.4172/2161-0533.1000e101.

21. Scott $\mathrm{S}$. Cauda equina syndrome secondary to lumbar disc herniation. Neurosurg 1993;32(5):743-7. https://doi.org/10.1227/00006123-199305000-00007.

22. Suk KS, Lee HM, Moon SH, Kim NH. Recurrent lumbar disc herniation: Results of operative management. Spine (Phila Pa 1976) 2001;26(6):672-6. https://doi.org/10.1097/00007632-200103150-00024.
23. Kaushal $P$, Jha R, Kumar $P$, Sharma GR. Lumbar disc herniation in children and adolescents: A case series. Nepal J Neurosci 2012;9:17-20.

24. Udama FU, Fokam PG, Motah M. Uncommon types of disc hernia (Areport of three cases and review of literature). Glob J Med Res 2011;11(2):42-8.

25. Weinstein JN, Lurie JL, Tosteson TD, Tosteson AN, Blood E, Abdu WA, et al. Surgical versus non-operative treatment for lumbar disc herniation: Four-year results for the Spine Patient Outcomes Research Trial (SPORT). Spine 2009;33(25):2789-800. https://doi.org/10.1097/BRS.0b013e31818ed8f4.

26. Peul WC, van den Hout WB, Brand R, Thomeer RT, Koes BW, LeidenThe Hague Spine Intervention Prognostic Study Group. et al. Prolonged conservative care versus early surgery in patients with sciatica caused by lumbar disc herniation: Two year results of a randomised controlled trial. BMJ 2008;336:1355-8.

https://doi.org/10.1136/bmj.a143.

27. Kleinstück FS, Fekete T, Jeszenszky D, Mannion AF, Grob D, Lattig F, et al. The outcome of discectomy for lumbar herniated disc is influenced by the severity of concomitant pre-operative low back pain. Spine 2010;1(1):44.

28. Smith GI. Coding Surgical Procedure. New York: Delmar; 2011.

29. Siddiq M, Ali N, Jan WA, Dil R. Surgical management of lumbar disc herniation by standard laminectomy in a periphery hospital; An experience with 64 patients. J Postgrad Med Inst 2011;17(1):20-5.

30. Ramirez LF, Javid MJ. Cost effectiveness of chemonucleolysis versus laminectomy in the treatment of herniated nucleus pulposus. Spine (Phila Pa 1976) 1985;10(4):363-7. https://doi.org/10.1097/00007632-198505000-00013.

31. Khattak AU, Haider A, Rehma A, llyas M. Surgical outcome of recurrent lumbar disc herniation: Experience with 30 patients. J Postgrad Med Inst 2009;23(1):86-9.

32. Hirsch JA, Singh V, Falco FJ, Benyamin RM, Manchikanti L. Automated percutaneous lumbar discectomy for the contained herniated lumbar disc: A systematic assessment of evidence. Pain Physician 2009;12:601-20.

33. Glenn JS, Yaker J, Guyer RD, Ohnmeiss DD. Anterior discectomy and total disc replacement for three patients with multiple recurrent lumbar disc herniations. Spine J 2011;11(9):e1-6.

https://doi.org/10.1016/j.spinee.2011.07.030.

34. McGirt MJ, Ambrossi GL, Datoo G, Sciubba DM, Witham TF, Wolinsky JP, et al. Recurrent disc herniation and long-term back pain after primary lumbar discectomy: Review of outcomes reported for limited versus aggressive disc removal. Neurosurgery 2009;64(2):338-44. https://doi.org/10.1227/01.NEU.0000337574.58662.E2.

35. Ambrossi GL, McGirt MJ, Sciubba DM, Witham TF, Wolinsky JP, Gokaslan ZL, et al. Recurrent lumbar disc herniation after single-level lumbar discectomy: Incidence and health care cost analysis. Neurosurgery 2009;65(3):574-8.

https://doi.org/10.1227/01.NEU.0000350224.36213.F9. 